\title{
Swim training as therapy of neurogenic induced unilateral shoulder instability in three horses
}

\author{
Stefan Rattenhuberl, Helen Benz' ${ }^{1}$ Zdzislaw Gajewski² and Bianca Carstanjen² \\ Tierklinik Seehof und Physiotherapie Center, Diessen, Germany' and Department for Large Animal Diseases, Faculty of Veterinary Medicine, Warsaw University \\ of Life Sciences, Warsaw, Poland ${ }^{2}$
}

\begin{abstract}
Summary
This case report describes swim training as a treatment of a traumatically induced unilateral paralysis of the suprascapular/brachialis nerves combined with shoulder instability in three horses. Two horses had a history of shoulder instability of three months duration and one horse of six months duration. All horses showed full-weight-bearing and shoulder stability of the affected limb after one month of swim training. Altogether, physiotherapy and swim training were performed for a period of two to 5.3 months. In two horses atrophy of the supraand infraspinosus muscles resolved completely. One horse showed moderate muscle atrophy at discharge. Swim training might be a valuable therapeutic option in horses affected with unilateral paralysis of the suprascapular / brachialis nerves.
\end{abstract}

Keywords: Swim training / rehabilitation / horse / Sweeny / N. suprascapularis / N. brachialis / paralysis

\begin{abstract}
Schwimmtraining als Rehabilitationsmethode bei neurogen bedingter unilateraler Schulterinstabilität bei drei Pferden
Dieser Fallbericht beschreibt Schwimmtraining als Therapie einer traumatisch bedingten unilateralen Paralyse des N. suprascapularis/brachialis in Verbindung mit einer Schulterinstabilität bei drei Pferden. Vorberichtlich wiesen zwei Pferde eine dreimonatige und ein Pferd eine sechsmonatige Krankheitsdaver auf. Alle Pferde zeigten eine vollständige Gewichtaufnahme und Stabilität der Schulter nach einem Monat Schwimmtraining. Physiotherapie und Schwimmtraining wurden über einen zwei- bis 5.3-monatigen Zeitraum durchgeführt. Die Atrophie der Ml. infra-/supraspinosus bildete sich bei zwei Pferden vollständig zurück. Ein Pferd zeigte bei Entlassung eine partielle Rückbildung der Muskelatrophie. Schwimmtraining scheint somit eine wertvolle Behandlungsmethode bei unilateraler Paralyse des N. suprascapularis/brachialis zu sein.
\end{abstract}

Schlüsselwörter: Schwimmtraining / Rehabilitation / Pferd / N. suprascapularis / N. brachialis / Paralyse

\section{Introduction}

Hydrotherapy is recognised for its benefits in the rehabilitation in humans (Luk et al. 2010, Salem and Gropack 2010) and small and large animals (Swanstrom and Lindy 1973, Harasen 2001). Peripheral nerve injury with associated shoulder instability is not uncommon in horses (Dyson 1986, MacKay 2006). Conservative and surgical therapy forms are described with variable clinical outcome (Adams et al. 1985, Schneider et al. 1985, Schneider and Bramlage 1990, Dutton et al. 1999). This case report describes the use and the successful outcome of swim training in three horses affected with unilateral shoulder instability and "sweeny" of neuronal origin.

\section{Case description}

Three Warmbloods $(\mathrm{H} 1-\mathrm{H} 3)$ - one mare and two stallions, aged one-, two- and four-years, with a whole body weight of $305 \mathrm{~kg}, 350 \mathrm{~kg}$, respectively and $545 \mathrm{~kg}$ - were included in this study. The horses were kept on pasture or were used as pleasure or, respectively show horses. The horses $(\mathrm{H} 1-\mathrm{H} 3)$ were presented at the clinic with unilateral shoulder instability i.e. shoulder slip, associated with an inability to bear weight on the affected forelimb (two left and one right forelimb). All horses had a history of an acute onset of lameness and shoulder instability due to a traumatism to the corresponding shoulder region in the pasture $\mathrm{H} \mathrm{H}$ and $\mathrm{H} 3$ were kicked by another horse; $\mathrm{H} 2$ had a downhill falling accident).
$\mathrm{H} 1$ and $\mathrm{H} 2$ had a history of lameness and shoulder instability of three months duration, whereas $\mathrm{H} 3$ had a history of six month duration. According to the referring veterinarians the horses were initially treated with systemic anti-inflammatory drugs for about three weeks and were housed in a stall with paddock. At admission all horses showed shoulder instability and a grade 4 out of 5 lameness of the affected forelimb. The hoof of the affected limb had a "club foot like" shape due to the changed biomechanical condition. Atrophy of the supra- and infraspinosus muscles was seen in all horses, moderately in $\mathrm{H} 1$ and $\mathrm{H} 2$, severe in $\mathrm{H} 3$ (Fig. 1). Further clinical examination, whole blood analysis and serum chemistry were normal $(\mathrm{H} 1-\mathrm{H} 3)$. X-rays of the corresponding shoulder (medio-lateral and skyline projection), humerus (medio-lateral projection) and elbow (medio-lateral and cranio-caudal projection) showed intact structures $(\mathrm{HI}-\mathrm{H} 3)$. Ultrasonography of the shoulder and the region of the scapula of the affected limb showed a decrease in muscle thickness without further pathological findings. Neurological examination showed skin sensation of the affected forelimb and shoulder in all horses $(\mathrm{H} 1-\mathrm{H} 3)$. The horses $(\mathrm{H} 1-\mathrm{H} 3)$ were treated systemically with systemic application of a vitamin B-complex (Vitamin BE-Komplex ${ }^{\mathrm{TM}}$, Selectavet GmbH, Weyarn-Holzolling, Germany; $15 \mathrm{ml}$ per day, IV for 3 weeks), corticosteroids (Dexasel $^{T M}$, Selectavet GmbH, Weyarn-Holzolling, Germany; $2 \mathrm{ml}$ every other day, IV for 3 weeks) and local topical application of anti-inflammatory and hyper-vascularizing ointment [(Kytta-Balsam ${ }^{\text {TM }}$, Merck Selbstmedikation GmbH, Darmstadt, Germany) in combination with (Phlogamed ${ }^{T M}$, Almaph- 
arm, Kempten, Germany)] for 4 weeks. After clinical examination and examination by diagnostic imaging tools, the horses $(\mathrm{H} 1-\mathrm{H} 3)$ were subjected to swim training for 5 days a week in a circular pool (diameter: $15 \mathrm{~m}$; depth: $3 \mathrm{~m}$ ) at a water temperature of $18^{\circ} \mathrm{C}$ (Fig. 2). Serum creatine kinase and lactate dehydrogenase of each horse were measured once a week, i.e. before and 4 to $5 \mathrm{hrs}$ after swim training.

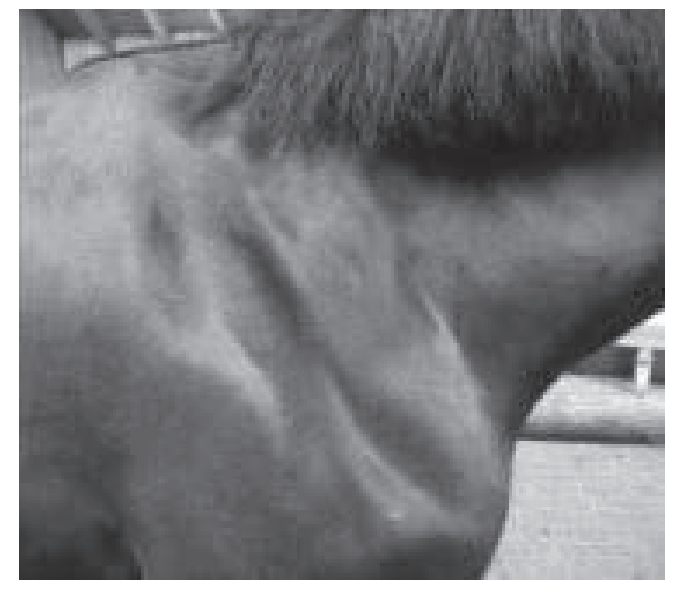

Fig. 1 Muscle atrophy of the supra- and infraspinosus muscles of the right forelimb in horse $3(\mathrm{H} 3)$. The horse was previously referred with a history of refractory "sweeny" and shoulder instability of 6 months duration.

Atrophie der Ml. supra- und infraspinosus der rechten Vordergliedmaße bei Pferd 3 (H3). Das Pferd wurde mit einem seit 6 Monaten andavernden "Sweeny" und Schulterinstabilität überwiesen.

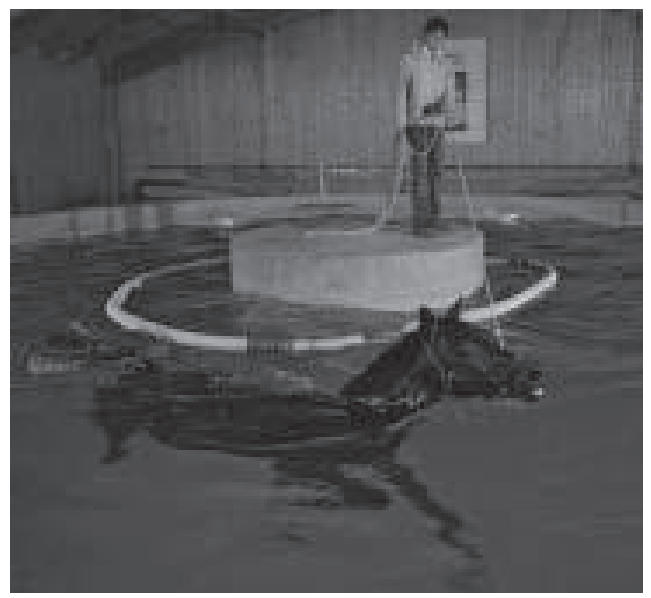

Fig 2 Swim training. All horses $(\mathrm{H} 1-\mathrm{H} 3)$ were exercised five times a week at a water temperature of $18^{\circ} \mathrm{C}$ and a swimming distance of 50 to 500 meters.

Schwimmtraining. Alle Pferde wurden fünfmal wöchentlich traininiert. Die Wassentemperatur betrug $18^{\circ} \mathrm{C}$ und die geschwommene Distanz lag bei 50 bis 500 Meter.

The swimming distance was progressively increased from $50 \mathrm{~m}$ during the first week to $500 \mathrm{~m}$ after $5-6$ weeks. Full functionality and full weight bearing of the affected limb was obtained after one month of swim training $(\mathrm{H} 1-\mathrm{H} 3)$. Overall, physiotherapy, i.e. passive extension and flexion of the affected limb (20min three times a week), and swim training were performed for 2.2 months $(\mathrm{H} 1), 2$ months $(\mathrm{H} 2)$ and 5.3 months $(\mathrm{H} 3)$ with the result that muscle atrophy of the supraand infraspinosus muscles was not present in two horses $(\mathrm{H} 1$, $\mathrm{H} 2)$, respectively was moderate in one horse $(\mathrm{H} 3)$.

\section{Discussion}

All horses of this study $(\mathrm{H} 1-\mathrm{H} 3)$ initially showed shoulder instability when bearing weight on the affected forelimb. The suprascapular nerve, which originates from the 6th and 7th cervical spinal cord segments, courses laterally and ventrally between supraspinatus and subscapularis muscles and courses around the scapula at the level of the incisura scapulae and ramifies to innervate the MI. supraspinatus and infraspinatus (MacKay 2006, Mayhew 2009). It has been suggested that further nerves, such as the pectoral nerve, the subscapular branch of the axillary nerve, the caudal cervical nerve roots and muscles such as pectoral, subclavius and subscapularis muscle or other supporting structures of the shoulder are damaged with injuries contributing to lateral shoulder instability and subluxation of the shoulder joint (Dyson 1986, Hahn et al. 1999, Dyson 2003). In addition to shoulder instability, all horses showed clinically an atrophy of the supraspinatus and infraspinatus muscles. Electromyography -performed more than one week post injury- might have been useful to identify further nerves of the brachial plexus that might have been injured in the study population. All three horses $(\mathrm{H} 1-\mathrm{H} 3)$ showed a marked acute unilateral shoulder instability (shoulder slip) as the affected limb bore weight. Various causes are possible, such as collision at speed with an object; stumbling, when galloping over uneven ground; stretching or compression of the nerve as it curves around the neck of the scapula or nerve compression by ill-fitting neck harness (Goble 2003, MacKay 2006, Mayhew 2009).

In the cases described, a direct trauma respectively or a trauma due to a downhill falling accident, caused the acute unilateral lameness. Especially in the acute phase following trauma the patient shows regional pain and reluctance to use the limb. In severe cases the shoulder slip is directly apparent. Clinical examination and diagnostic imaging e.g. such as $x-$ rays, and ultrasonography, allowed excluding various pathologies in the described three cases $(\mathrm{H} 1-\mathrm{H} 3)$, such as fractured cervical vertebrae, elbow, humerus, bicipital bursitis or cellulitis (Schneider and Bramlage 1990, Lopez et al. 1997). Peripheral nerve damage can be classified clinically and pathologically into three syndromes after Mayhew (2009). Neurapraxia, i.e. concussion of nerve fibers with no permanent morphologic change; axonotmesis, i.e. damage to axons with sparing of the Schwann cell-derived myelin sheaths, and neurotmesis, i.e. loss of integrity of axons and their myelin sheaths. In case of partial nerve damage, sprouts from the neuromuscular terminals of surviving fibers should find denervated muscle and the function should be restored within several weeks. Complete axonal injury results in "sweeny", i.e. muscle atrophy and recovery depends on axonal sprouts from the proximal stump of the suprascapular nerve. Nerve damage of the cases described $(\mathrm{H} 1-\mathrm{H} 3)$ might be neurapraxia as well as axonotmesis/neurotmesis. In case of the latter, the nerve's return to function relies on axonal re-growth of up to $300 \mathrm{~mm}$ over about 6-12 months (Mayhew 2009). But nerveregeneration must be performed before irreversible muscular fibrosis occurs. Modest exercise and physiotherapy such as swim training might therefore be beneficial to axonal regrowth.

In humans, the movement of joints without weight bearing is considered valuable. The advantage of swimming is easing 
the burden on joints, muscles and tendons, and simultaneous activation of numerous muscles which are combined with nearly identical motions (Bartmann 1991, Rattenhuber 2007). However, the monitoring of muscle enzymes is of uppermost importance to avoid over-training or exhaustion (Bartmann 1991). The patients are able to use the injured limb sooner than with the conventional therapy. In addition, water has a massage-effect and promotes the circulation (Rattenhuber 2007). Although horses are considered to be non-swimmers (Bromiley 2007), swim training has been investigated for training purpose in sound horses (Bartmann 1991), for fitness check-ups (Bartmann 1991), and in the therapy of orthopedic diseases (Swanstrom and Lindy 1973). Data of swim training in the rehabilitation of horses with peripheral nerve damage are presently not available to the authors' knowledge. The resistance supplied by the water is even; therefore the swimmer adopting a four-limb sequence will correctly use and therefore exercise the muscles of shoulders, hindquarters and back (Bromiley 2007). Maintaining exercise, physiotherapy such as passive range of motion, faradic stimulation and swimming is beneficial as therapy of paresis in large animals (White and White 1995). Conservative and surgical therapy of shoulder instability and "sweeny" due to peripheral nerve damage are described with various outcome and complications (Schneider and Bramlage 1990, Dutton et al. 1999). Atrophy of the supra- and infraspinatus muscles does not resolve completely in all cases (Adams et al. 1985, Dutton et al. 1999). Conservative therapy with stall rest alone allowed a good return to function in 7 of 8 horses within 3 to 12 months, whereas shoulder stability took about 7 months to return, shoulder atrophy resolved only in 2 of 8 horses (Dutton et al. 1999).

In $\mathrm{H} 1$ and $\mathrm{H} 2$, function and shoulder stability took one month of swim training to redevelop. The remaining case $(\mathrm{H} 3)$ had already been treated conservatively for 6 months without any success. The horse was subjected to swim training and function and shoulder stability established within one month of exercise. The shoulder atrophy improved, but did not resolve completely after 5.3 months of swim training. Surgical resection of scar tissue surrounding the nerve, i.e. external neurolysis, might facilitate the damaged nerve's re-growth and reduce tension on the nerve as it crosses the front of the scapula and an early approach might be indicated in show horses (Adams et al. 1985, Schneider et al. 1985, Schneider and Bramlage 1990). Rasping the cranial part of the scapula might decompress the suprascapular nerve, but bears the risk of accidental supraglenoid tubercle fracture or scapular neck fracture following surgery in 10\% of the operated cases (Schneider and Bramlage 1990). On the other hand it was shown that surgical therapy might diminish the degree of shoulder muscle atrophy, and the horse might return to function sooner (Schneider et al. 1985, Dutton et al. 1999). It was decided to treat the three horses of this study $(\mathrm{H} 1-\mathrm{H} 3)$ conservatively combined with physiotherapy, because in the long term there did not seem to be a difference between conservative and surgical therapy (Adams et al. 1985, Schneider et al. 1985, Schneider and Bramlage 1990, Dutton et al. 1999). All three horses were free of lameness. Two of the three horses $(\mathrm{H} 1, \mathrm{H} 2)$ in this study showed a complete recovery of muscle atrophy whereas one horse $(\mathrm{H} 3)$ showed a progressive improvement of the atrophy associated with swim exercise.
In conclusion, swim training could be a valuable therapy tool in horses with unilateral shoulder instability and "sweeny" of neuronal origin. A prospective randomized study with large sample size is warranted to support our clinical observation.

\section{References}

Adams O. R., Schneider R. K., Bramlage L. R., Easley K. J. and Schneider J. E. (1985) A surgical approach to treatment of suprascapular nerve injury in the horse. J. Am. Vet. Med. Assoc. 187, 1016-1018

Bartmann M. (1991) Leistungsphysiologische Untersuchungen zum Schwimmtraining von Sportpferden. Diss. Med. Vet. München

Bromiley M. (2007) Rehabilitation. In: Equine injury, therapy and rehabilitation. Bromiley M., ed. 3rd ed. Oxford: Blackwell, 130-159

Dutton D. M., Honnas C. M. and Watkins J. P. (1999) Non-surgical treatment of suprascapular nerve injury in horses: 8 cases (19881998). J. Am. Vet. Med. Assoc. 214, 1657-1659

Dyson S. J. (1986) Shoulder lameness in horses: an analysis of 58 suspected cases. Equine Vet. J. 18, 29-36

Dyson S. J. (2003) The Elbow, Brachium and Shoulder. In: Diagnosis and Management of Lameness in the Horse. Ross M.W., Dyson S.J., eds. 1st ed. WB Saunders, Philadelphia, USA, 399-416

Goble D. O. (2003) Lameness in draft horses. In: Diagnosis and Management of Lameness in the Horse. Ross, M.W., Dyson, S.J., eds. 1st ed. WB Saunders, Philadelphia, 1058-1069

Hahn C. N., Mayhew I. G. and MacKay R. J. (1999) Diseases of the peripheral (spinal) nerves. In: Equine medicine and surgery. Colahan P. C., Mayhew I. G., Merritt A. M., Moore J. N. eds. 5th ed. Mosby, St Louis, USA

Harasen G. (2001) Postoperative physical therapy in orthopedic patients. Can. Vet. J. 42, 655

Lopez M. J., Nordberg C. and Trostle S. (1997) Fracture of the 7th cervical and 1 st thoracic vertebrae presenting as radial nerve paralysis in a horse. Can. Vet. J. 38, 112

Luk K. D., Wan T. W., Wong Y. W., Cheung K. M., Chan K. Y., Cheng A. C., Kwan M. W., Law K. K., Lee P. W. and Cheing G. L. (2010) A multidisciplinary rehabilitation program for patients with chronic low back pain: a prospective study. J. Orthop. Surg. (Hong Kong) 18, 131-138

MacKay R. J. (2006) Peripheral nerve injury. In: Equine Surgery. Auer J. A., Stick J. A., eds. 3rd ed. WB Saunders, St Louis, USA 684-691

Mayhew J. (2009) Physical and chemical causes. In: Large animal neurology. Mayhew J., ed. 2nd ed. Blackwell, Oxford, UK, 294-320

Rattenhuber S. (2007) Behandlung von akuten Sehnenerkrankungen und deren physiotherapeutische Nachbehandlungen. Proceedings of the Bayerische Tierärztetag, Nürnberg, Germany

Salem Y. and Gropack S. J. (2010) Aquatic therapy for a child with type III spinal muscular atrophy: a case report. Phys. Occup. Ther. Pediatr. 30, 313-324.

Schneider J. E., Adams O. R., Easley K. J., Schneider R. K., Bramlage L. R., Peter J. and Boero M. J. (1985) Scapular notch resection for suprascapular nerve decompression in 12 horses. J. Am. Vet. Med. Assoc. 187, 1019-1020

Schneider R. K. and Bramlage L. R. (1990) Suprascapular nerve injury in horses. Comp. Cont. Educ. Pract. Vet. 12, 1783-1789

Swanstrom O. and Lindy M. (1973) Therapeutic swimming. In: Proceedings. 19th Annu. Conv. AAEP, 315-322.

White A. J. and White V. J. (1995) Physiotherapy as an aid to treatment of bilateral femoral paralysis in a calf. Vet. Rec. 137, 489-491

Prof. Dr. Bianca Carstanien, PhD

Department for Large Animal Diseases

Faculty of Veterinary Medicine

Warsaw University of Life Sciences

Nowoursynowska 100

02-786 Warsaw

Poland

bcarstanjen@web.de 